Вісник Харківського національного університету імені В.Н. Каразіна Серія "Математика, прикладна математика і механіка"

Toм 87, 2018, c. 29-41

УДК 51-76
Visnyk of V.N.Karazin Kharkiv National University Ser. "Mathematics, Applied Mathematics and Mechanics"

Vol. 87, 2018, p. 29-41

DOI: $10.26565 / 2221-5646-2018-87-03$

\title{
Mathematical model of liver regeneration processes: homogeneous approximation
}

\author{
V. V. Karieva, S. V. Lvov \\ V. N. Karazin Kharkiv National University, \\ Kharkiv, 4 Svobody sqr., 61022, Ukraine \\ valerija.kareva@gmail.com,lvovser@gmail.com
}

This paper deals with the rules and the mechanisms regulation of liver regeneration. The generalized mathematical model was developed. This model has an explicit dependence on the control parameters. To solve this problem there were accepted such assumptions: homogeneous approximation; small toxic factors.

Keywords: mathematical model, liver regeneration, homogeneous approximation

Карєва В. В., Львов С. В. Математична модель процесів регенерації печінки: однорідне наближення. У статті розглядаються правила й механізми регуляції процесів регенерації печінки. Було розроблено узагальнену математичну модель, що явно залежить від керуючих параметрів. Для цього були зроблені наступні припущення: однорідне наближення; помірний токсичний вплив.

Ключові слова: математична модель, регенерація печінки, однорідне наближення

Карева В. В., Львов С. В. Математическая модель процессов регенерации печени: однородное приближение. В статье рассматриваются правила и механизмы регуляции процессов регенерации печени. Была разработана обобщенная математическая модель в явной зависимости от управляющих параметров. При этом были сделаны следующие предположения: однородное приближение, умеренное токсическое воздействие.

Ключевые слова: математическая модель, регенерация печени, однородное приближение.

2010 Mathematics Subject Classification: 92C37, 65C20.

\section{Introduction}

The defining of principles and rules regulation of biological processes during development and maintenance/restoration (regeneration) of dynamic organs' and tissues' homeostasis is one of the most important fundamental problems in theoretical Biology and Medicine.

Liver diseases are an important medical problem. Knowledge about the rules and mechanisms of liver regeneration is the basis for the development of new

(c) V.V. Karieva, S. V. Lvov, 2018 
effective medicaments and the choice of rational strategies for the therapy of liver diseases.

The regeneration processes in liver represents particular interest. The liver has the greatest plasticity and the largest set of possible regeneration strategies. In addition, there are a large experimental data that enable to elaborate and prove mathematical models for study liver regeneration in silico and their verification in vivo [1].

The processes of liver regeneration and their mathematical models have been studied in the many interdisciplinary projects $[2,3,4]$.

Despite of the achievements in the field of modeling of the liver regeneration processes there are still enough "difficult"problems requiring the new ideas, approaches and methods of justification and development of mathematical models.

The mathematical models of liver regeneration can be considered as dynamic networks of intracellular processes and processes of cell-cell communication. Such non-linear dynamic networks are extremely complex. They can represent processes in hundreds of millions of cells of different types and much more interactions between them.

Such mathematical models of liver regeneration processes can have an almost unlimited set of potentially possible parametric phase organization.

However, in the experiment we observe only a limited number of strategies and qualitative phenomena of maintenance and restoration (regeneration) of the liver's dynamic homeostasis. It can be supposed that the processes of liver regeneration are the subject of some control which provides "regularization"of the dynamics of the whole system.

According to one of the most general hypothesis of theoretical biology the regulation processes of maintaining and restoring dynamic homeostasis is realized due to the phenomenon of appearing self-organization in a complex dynamic network of interacting liver cells [5]. But the common rules and mechanisms of the self-organization and regulation of liver regeneration observed in the experiment are unknown.

The mathematical cell biology at the present time is an empirical discipline. It is represented by a set of experimental data, knowledge and rules that are derived from the experiment and determine the properties of the system and its possible dynamics.

At the modern biological experimental technology we are not able to observe many crucial molecular processes that occur in the cell during liver regeneration. Consequently, the mathematical models of liver regeneration assume a large number of hypotheses about the rules of regulation. Verification of these hypotheses requires a large number of high-cost experiments.

One possible way to solve the problems associated with the complexity and non-observability of the biological processes of liver regeneration is based on the following assumption.

\section{The main hypothesis.}

The regulation of processes of maintaining/restoring the dynamic liver homeostasis based on the appearing self-organization is provided according to 
some principles, the optimal criteria which are formed during the organism's evolution.

These principles and criteria are true for any level of detail description of the processes of liver regeneration. The regulation of processes that we do not observe in the experiment or cannot characterize because of their extreme complexity is subjected to these principles and criteria.

One of the main approaches to the development of mathematical models of biological systems of interacting cells is the agent model based on empirical rules [6].

In this approach the agent represents some "input-state-output"model of the cell (group of cells). The network of interactions between agents are defined as maps that connect the outputs and inputs of agents. These maps determine the collective dynamics of the network, depending on the state of agents.

Even at the generalized level of description of process, such networks contain hundreds of thousands of parameters. It is not possible to solve the problems of verification of various hypotheses about the principles and criteria of regulation using such models.

Thus, in order to confirm hypotheses simple ("toy") models in explicit dependence on the control parameters are required.

\section{Phenomenological description of liver regeneration processes}

The liver is the central metabolic organ of vertebrates. First, the liver keeps the concentration of numerous plasma compounds such as amino acids, fatty acids, nucleosides, plasma proteins, and lipoproteins within a narrow concentration range at varying physiological conditions (e.g., starvation or physical exercise), to ensure an almost constant metabolic environment for non-hepatic tissues. This homeostatic function includes the transient storage in the liver of carbohydrates and lipids. Second, the liver provides secretion of bile. Hepatic production of bile is needed for the efficient intestinal digestion of lipids and serves as the excretion pathway for metabolic waste products, many xenobiotics and also cholesterol. Finally, the most important function of the liver is to detoxify endogenous and exogenous compounds and remove pathogens [7].

Most of the metabolic functions are undertaken by parenchymal cells (hepatocytes and cholangiocytes), which make up about two-thirds of the organ's cell population, and possessing the most versatile metabolic function of all human cell types. Removal of pathogens and antigens is predominantly accomplished by hepatic endothelial cells and liver macrophages (hepatic Kupffer cells). Hepatic stellate cells are involved in the formation of the connective tissue of the liver and actively contribute to liver fibrosis after damage or injury of the organ. Resident stem cells can be transformed into almost any type of liver cell. Stem/progenitor cells are among the most resistant cells in relation to various damaging factors and play a major role in the regeneration processes $[8,9]$.

The smallest structural division of the liver is the liver lobule. It takes the approximate shape of a hexagonal prism with a size of 1-2 $\mu \mathrm{m}$ and consists of all 
types of liver cells. The number of lobules in the liver can range from hundreds of thousands to a million, depending on the body.

Presently there are two main types of liver regeneration.

1. When the liver is severely damaged or toxic factors are strong, the liver regeneration process occurs due to the replication of liver stem / progenitor cells and stellate cells. Stem cells can differentiate into liver parenchymal and epithelial cells. And stellate cells provide reparative fibrosis processes [10, 11, 12].

2. In the case of partial (two/thirds) surgical hepatectomy $(\mathrm{PH})$ or small toxic factors, the regeneration process does not require such stem / progenitor cells or fibrosis $[13,19]$.

In the second type the liver regeneration occurs due to hyperplasia processes, replication and division of binuclear hepatocytes into mononuclear.

All of the above processes are aimed at increasing the functional activity of the liver. As the main functional cells we consider only hepatocytes of various types. Each of the different types of hepatocytes in a lobule has its own index of functionality. This coefficient determines how efficiently the cell performs its functions. The hyperplasia process increases the functionality of the liver by increasing the protein complexes. Polyploid and binuclear hepatocytes function more efficiently due to the increased number of chromosomes. As a result of the replication process, two fully functioning cells are formed.

Each of these processes has its characteristic time. Under ideal conditions, replication lasts 24 hours, the transition to polyploidy - 12 hours, hyperplasia - 6 hours, the division of binuclear hepatocytes - 1 hour. The main processes of liver regeneration occur in heterogeneous conditions of external stress, which leads to a significant increase in their characteristic times. Also different types of hepatocytes have different indicators of resistance to toxic factors and the rate of increase in their functionality due to hyperplasia. For example, due to the greater number of chromosomes polyploid and binuclear hepatocytes are more resistant to toxic factors.

\section{General process model}

A mathematical model of liver regeneration processes is considered for the second type of liver regeneration (liver resection or small toxic factors).

In our model the hepatic lobule is represented in the form of its cellular structure. Lobules are about a million in the liver.

The cellular structure of the lobules is the same in space - homogeneity. Toxic factors are evenly distributed throughout the liver cells. The processes occurring in different lobules are independent.

Under the assumptions of homogeneity and independence, an approximation on average is valid. It gives the equations of population dynamics for various types of liver cells.

In the idealized limited case the possible formulation of the optimization problem can be considered as follows. 
1) An equation which describes the dynamics of populations of liver cells:

$$
\bar{x}(t+1)=f(\bar{x}(t), \tau(t), \bar{\lambda}(t)),
$$

where $\bar{x}(t)$ - types of functional liver cells at moment $t, \tau(t)$ - given function of external toxicity, $\bar{\lambda}(t)$ - control parameters.

Each type of cells has its own index of functionality and calculate the function $\Phi(t)=\sum_{i=0}^{m} c_{i}\left(x_{i}(t), \tau(t)\right)$ - generalized liver function index.

2) An equation which describes the change in the functional state of the organism depending on the function of external toxicity $\tau(t)$ and the functional state of the liver $\Phi(t)$ :

$$
\widetilde{\Phi}(t+1)=\Psi(\tau(t), \Phi(t)) .
$$

Consider an abstract organism as the result of a potentially feasible experiment of synthetic evolution for a sufficiently large chain of generations of populations. We believe that each generation is subject to a typical stress $\tau(t)$.

A necessary condition for successful evolutionary selection is not a break of the evolutionary chain, but its result is a strategy for achieving suboptimal functional activity of the organism $\bar{\lambda}(t)$.

An example of an optimal control problem criterion which satisfies these requirements:

$$
\sum_{t=0}^{T}(K-\widetilde{\Phi}(t))^{2}+A \widetilde{\Phi}\left(T^{\prime}\right) \leq E
$$

under the condition

$$
\sum_{t=T_{0}^{\prime}}^{T^{\prime}} I(\widetilde{\Phi}(t)) \geq C
$$

where

$$
I(\widetilde{\Phi}(t))= \begin{cases}1 & \text { if }(K-\widetilde{\Phi}(t))^{2} \leq E \\ 0 & \text { otherwise }\end{cases}
$$

Where $T$ - the end of the life cycle of the body, $T_{0}^{\prime}\left(T^{\prime}\right)$ - moment of the beginning (end) of the reproductive period, $K$ - optimal functional activity of the body, $E$ - a constant defining the set of reachability of the functional activity of the organism, $C-$ a constant which is responsible for the survival of the organism.

The regulation of biological processes is determined by the processes of selforganization of the cellular network, which appeared during stress disturbances. Phase transitions define some virtual control system $\bar{\lambda}(t)=M(\tau(t), \bar{x}(0))$, which has the self-criticality property $[14,15]$.

\section{Mathematical models of processes}

In our model the cellular structure of the liver at each time moment is described by the following parameters:

- $\Gamma(t)$ - the number of normal hepatocytes at moment $t$; 
- $\Gamma_{2}(t)$ - the number of diploid hepatocytes at moment $t$;

- $\Gamma_{4}(t)$ - the number of tetraploid hepatocytes at moment $t$;

- $\Gamma^{2}(t)$ - the number of binuclear hepatocytes at moment $t$ t;

- $\Gamma_{g i p}(t)$ - the number of hepatocytes in a state of hyperplasia at moment $t$;

- $A s(t)$ - the number of hepatocytes in a state of antistress at moment $t$;

- $A p(t)$ - the number of hepatocytes in a state of apoptosis at moment $t$;

- $N(t)$ - the number of hepatocytes in a state of necrosis at moment $t$.

Toxic factors - Tox $(t)$ :

- $\tau(t)$ - the external toxicity (exotoxicity) at moment $t$;

- $D P(t)$ - the internal toxicity due to decay products of necrosis (endotoxicity) at moment $t$.

The system dynamics is defined by the following control parameters and transition rules.

- $a(t)$ - the relative number of hepatocytes which are initiated to enter the cell-division cycle;

- $b(t)$ - the relative number of hepatocytes which are initiated into polyploidy;

- $b_{2 j}(t)$ - the relative number of hepatocytes which are initiated into binuclear cells;

- $a_{2 j}(t)$ - the relative number of hepatocytes which are initiated from binuclear hepatocytes per division;

- $g(t)$ - the relative number of hepatocytes which are initiated into hyperplasia;

- $\omega(t)$ - the relative number of hepatocytes which are initiated into controlled apoptosis. This parameter is different for each type of cell.

Considering the fact that the characteristic times of the main processes are significantly different and the processes depend on the external (non-stationary) toxic factors, each such process must be modeled separately.

Assume that all simulated processes are cyclical. In general, the transition to a new cycle, exit from a cycle or a new process is determined by the control parameters.

The discrete state space of the process is a set of states $(1,2, \ldots, n)$, where the number of states $n$ is determined from the characteristic time of the process in ideal conditions and the discrete interval. 


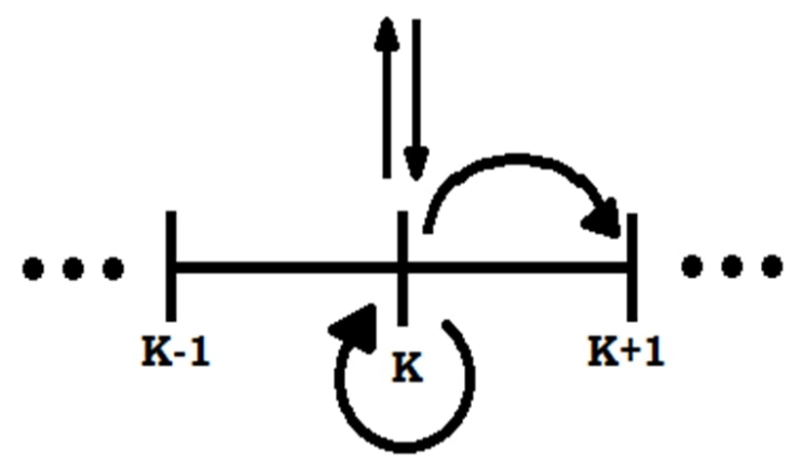

Fig. 1. The discrete state space of the process.

Also, there is competition parameter in our mathematical model:

$$
k(t)=1-\frac{1}{K}\left(\Gamma(t)+\Gamma_{2}(t)+\Gamma_{4}(t)+\Gamma^{2}(t)+\Gamma_{g i p}(t)\right)
$$

where $k(t)$ - coefficient of competition for the resource, $K$ - environment capacity.

\subsection{Replication process and transition processes during replication}

Under normal conditions the replication process takes place within 24-32 hours during the cell-division cycle.

Our model assumes that the following events may occur during replication: cell doubling (completed replication), cell transition to polyploidy, cell transition to binuclear cell.

The replication process and the indicated transitions are inherent for normal (diploid) hepatocytes, tetraploid hepatocytes and hepatocytes in a state of hyperplasia.

The cell cycle consists of strictly deterministic series of sequential processes [17]:

1) the preparatory phase for cell division - "interphase"consisting of phase $G 1$, phase $S$ and phase $G 2$,

2) the period of cell division - "mitosis"(phase $M$ ).

Usually the interphase takes at least $90 \%$ of the time of the entire cell cycle (the $M$ phase lasts 1-2 hours).

The $G 1$ phase and $G 2$ phase are intermediate phases. DNA replication occurs in the $S$ phase. As a result of the doubling of DNA molecules, each chromosome has twice as much DNA as it was before the $S$ phase, i.e. the amount of DNA in diploid cells corresponds to the tetraploid set. As a result of mitosis (phase $M$ ) two daughter cells with the same set of chromosomes arise from one cell. 
During the cell-division cycle the cell passes the so-called "checkpoints". Checkpoints prevent cell cycle progression at specific points, allowing verification of necessary phase processes and repair of DNA damage. In case of failure to pass checkpoint the cell is sent for apoptosis. There are three most important points: the $G 1$ (restriction) checkpoint, the $G 2$ (DNA damage) checkpoint and the mitotic (spindle) checkpoint [18].

Under the control signal $b(t)$ some cells exit the cell cycle and return to functioning as polyploid cells. A such transition can occur in the $S$ phase of the cell cycle.

In the middle of mitosis some cells exit the cell cycle under the control signal $b_{2 j}(t)$ and turn into dual-core cells that perform the normal functions of the hepatocyte. Binuclear hepatocytes under the control signal $a_{2 j}(t)$ complete the cell cycle and form two normal cells.

The replication cycle and possible controlled transitions are shown in next figure:

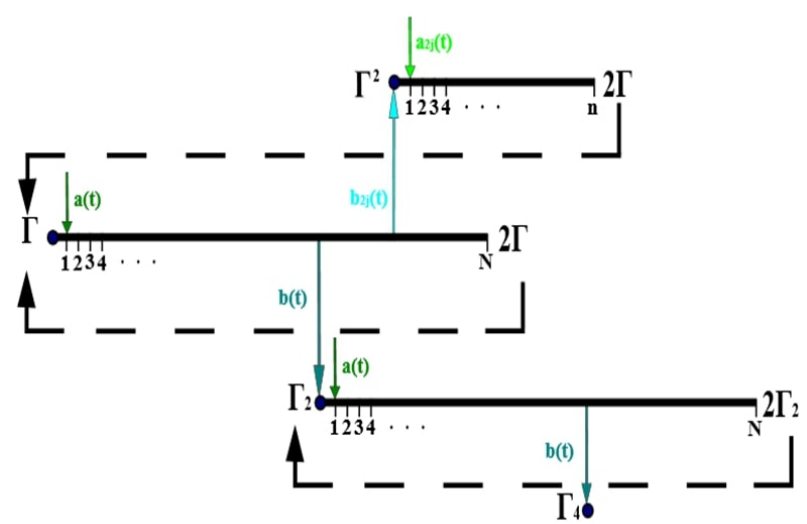

Fig. 2. Replication process and transition processes during replication.

Population dynamics of normal hepatocytes, polyploid hepatocytes and binuclear hepatocytes:

$$
\begin{gathered}
\Gamma(t+1)=\Gamma(t)-a(t) k(t) \Gamma(t)+2 \mu(\operatorname{Tox}(t)) \Gamma(t)+a_{2 j}(t) \Gamma^{2}(t)-g(t) \Gamma(t)- \\
-\omega(t) \Gamma(t)-k(t) b(t) \Gamma(t)-r(\operatorname{Tox}(t)) \Gamma(t)+A s(t) \\
\Gamma_{2}(t+1)=\Gamma_{2}(t)-a(t) k(t) \Gamma_{2}(t)+2 \mu(\operatorname{Tox}(t)) \Gamma_{2}(t)+k(t) b(t) \Gamma(t)-g(t) \Gamma_{2}(t)- \\
-k(t) b(t) \Gamma_{2}(t)-\omega(t) \Gamma_{2}(t)-r(\operatorname{Tox}(t)) \Gamma_{2}(t)+A s(t) \\
\Gamma^{2}(t+1)=\Gamma^{2}(t)+b_{2 j}(t) \Gamma(t)-a_{2 j}(t) \Gamma^{2}(t)-g(t) \Gamma^{2}(t)-\omega(t) \Gamma^{2}(t)-
\end{gathered}
$$




$$
-r(\operatorname{Tox}(t)) \Gamma^{2}(t)+A s(t)
$$

Where: $\mu(\operatorname{Tox}(t))$ - the cycle parameter; $r(\operatorname{Tox}(t))$ - the parameter that sends cells to necrosis under high toxicity.

\subsection{Hyperplasia}

The hyperplasia process is an additional expression of intracellular molecular complexes and structures that provide an increase in its functional activity [19].

Hyperplasia consists of cycles. In each cycle protein expression occurs and the number of protein complexes is increased in the cell. One cycle of hyperplasia lasts about an hour. It should be noted that for polyploid and binuclear hepatocytes the hyperplasia process occurs faster due to the greater number of DNA.

The process of hyperplasia can be performed for all types of cells.

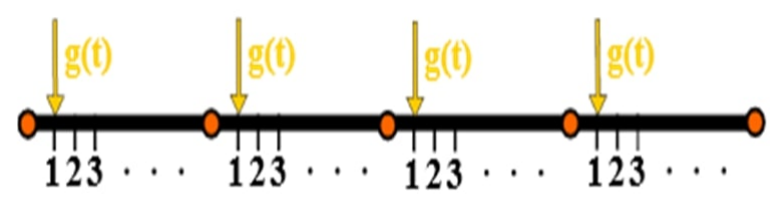

Fig. 3. Hyperplasia process.

The initialization of the hyperplasia process is controlled by the parameter $g(t)$ which determines the relative number of hepatocytes for hyperplasia.

The equation of dynamics for hepatocytes in a state of hyperplasia:

$$
\begin{aligned}
\Gamma_{g i p}(t+1)=\Gamma_{g i p}(t)+ & g(t)\left(\Gamma(t)+\Gamma_{2}(t)+\Gamma_{4}(t)+\Gamma^{2}(t)\right)-\omega(t) \Gamma_{g i p}(t)- \\
& -r(\operatorname{Tox}(t)) \Gamma_{g i p}(t)+A s(t)
\end{aligned}
$$

\subsection{The process of the cell antistress request}

When toxic factors act on the cell, the so-called antistress program is launched [20].

The antistress program involves several cycles of expression of antistress protein complexes that can neutralize toxic factors. Each cycle lasts about 15 minutes. In our mathematical model it is assumed that the antistress program has the highest priority and it cancels all other processes.

Note that hepatocytes in the $S, M$ phase of the cell cycle cannot start the antistress program because in these phases the DNA of the cell is not functional.

If after one cycle of the antistress program the effect of toxic factors on the cell decreased, the cell completes the antistress process and returns to the interrupted process. However, if the effect of toxic factors on the cell still the same, the cell 
goes on a new cycle of the antistress program. Due to the failure of the antistress program, the cell goes into either apoptosis or necrosis depending on the level of toxic factors [20].

The equation of dynamics for hepatocytes in a state of antistress:

$$
\begin{gathered}
A s(t+1)=A s(t)+\mu(\operatorname{Tox}(t))\left(\Gamma(t)+\Gamma_{2}(t)+\Gamma_{4}(t)+\Gamma^{2}(t)+\Gamma_{g i p}(t)\right)- \\
-\omega(t) A s(t)-r(\operatorname{Tox}(t)) A s(t)-A s(t)
\end{gathered}
$$

\subsection{Apoptosis}

Apoptosis is closely associated with programmed cell death [20]. The mechanisms of apoptosis are triggered when the toxic factors are not strong enough to cause necrosis. The body responds to the danger of mass cell death with a kind of protection - suicide of a relatively small number of cells so that the factors of pathological effects are not so great.

As a result of apoptosis the decay products of a cell are almost immediately destroyed by resident macrophages and do not have a toxic effect on neighboring cells. The apoptosis is quite a long process, it takes more than 24 hours.

Note that the body is able to purposefully reduce cell populations. This ability of the body is called controlled apoptosis.

In our model controlled apoptosis occurs under the control signal $\omega(t)$ - the relative number of hepatocytes which are initiated into controlled apoptosis. This parameter is different for each cell type.

The equation for cells in a state of apoptosis is:

$$
A p(t+1)=A p(t)+\omega(t)\left(\Gamma(t)+\Gamma_{2}(t)+\Gamma_{4}(t)+\Gamma^{2}(t)+\Gamma_{g i p}(t)\right)-r(T o x(t)) A s(t)
$$

\subsection{Necrosis}

Uncontrolled cell death as a result of effect of a strong toxic factors on the cell is called necrosis [20].

During necrosis process the decay products of necrosis (DP) are appeared. They form internal toxicity. Necrosis decay products are highly toxic factors for surrounding cells. Their action can lead to stopping of the regeneration processes, apoptosis and even necrosis of the surrounding cells.

The necrosis process proceeds fairly quickly (about one hour).

Due to the locality of necrosis its distribution should be described using spacetime mathematical models. However we make an assumption about the environment uniformity. Consequently the spread of necrosis occurs regardless of the location of the necrotic cell in space (suppose that one necrotic cell affects some number of healthy cells per unit of time).

$$
N(t+1)=N(t)+r(\operatorname{Tox}(t))\left(\Gamma(t)+\Gamma_{2}(t)+\Gamma_{4}(t)+\Gamma^{2}(t)+\Gamma_{g i p}(t)+A s(t)+A p(t)\right)
$$




\subsection{Toxicity}

Common toxicity consists of two factors: external (given function) and internal toxicity due to the toxicity of the decay products as a result of necrosis.

$$
\operatorname{Tox}(t)=D P(t)+\tau(t)
$$

The equation which describes change of external toxicity:

$$
\tau(t+1)=\tau(t)-\tau(t) x(t)-\tau(t) e_{1}
$$

where $x(t)=\sum_{k} c_{k} \Gamma(t)$ - toxicity reduction coefficient due to functional activity of hepatocytes, $e_{1}$ - toxicity reduction coefficient due to blood flow.

The equation which describes change of internal toxicity:

$$
D P(t+1)=D P(t)-D P(t) F-D P(t) e_{2}
$$

where $F$ - toxicity reduction coefficient due to phagocytic activity, $e_{2}$ - toxicity reduction coefficient due to blood flow.

Remark. $e_{2}<e_{1}$, the decay products of necrosis act locally and external toxicity affects a large area.

\section{Conclusion}

The developed model is linear in control parameters. It is important for solving optimal control problems.

This model will be the basis for the development of a more complex model for considering the regeneration strategies of the first type.

It is supposed to justify the principles and criteria for optimal regulation of liver regeneration processes and verify them in numerical experiments based on the developed model.

The proposed model of population dynamics includes such models of population dynamics as the generalized Lotka-Volterra equations, the Lotka-Volterra equations with transitions, the Lotka-Volterra delay equations, the Volterra integro-differential equations[16].

\section{REFERENCES}

1. B. Christ, U. Dahmen, K-H. Herrmann, M. Konig, JR. Reichenbach, T. Ricken, J. Schleicher, L. Ole Schwen, S. Vlaic, N. Waschinsky. Computational Modeling in Liver Surgery. Frontiers in Physiology. - 2017. - Vol. 8. Article 906. - P.1-26. DOI: 10.3389/fphys.2017.00906

2. Virtual Liver Network: A major national initiative funded by the German Federal Ministry for Education and Research, 2010-2015. http://www.virtual-liver.de/ 
3. LiSyM - Liver Systems Medicine: Research network of German centers and institutions, 2016-2020. - http://www.lisym.org/

4. D. Cook, B. A. Ogunnaike, R. Vadigepalli. Systems analysis of nonparenchymal cell modulation of liver repair across multiple regeneration models. BMC Systems Biology, - 2015. - Vol. 9:71. - P.1-24. DOI: 10.1186/s12918-015-0220-9.

5. Ye. Dayong, Zh. Minjie, V. Athanasios. Computational Modeling in Liver Surgery. IEEE Transactions on Systems, Man, and Cybernetics. -2017. Vol. 47. No. 3. - P. 441-462.

6. M. Hwang, M. Garbey, S. A. Bercali, R. Tran-Son-Tay. Rule-Based Simulation of Multi-Cellular Biological Systems-A Review of Modeling Techniques. Cellular and Molecular Bioengineering. - 2009. - Vol. 2(3). - P. 285-294.

7. H. Holzhutter, D. Drasdo, T. Preusser, J. Lippert, A.M. Henney. The virtual liver: a multidisciplinary, multilevel challenge for systems biology. WIREs Syst Biol Med. - 2012. - Vol. 4(3). - P.221-235.

8. K. Jungerman. Metabolic zonation of liver parenchyma. Semin Liver Dis. 1988. - Vol. 8. - P. 329-341.

9. K. Jungermann, T. Kietzmann. Oxygen: modulator of metabolic zonation and disease of the liver. Hepatology. - 2000. - Vol. 31. - P. 255-260.

10. MR. Alison, S. Islam, S. Lim. Stem cells in liver regeneration, fibrosis and cancer: the good, the bad and the ugly. J Pathol. - 2009. - Vol. 217(2): P. 282-298.

11. KS. Zaret, M. Grompe. Generation and regeneration of cells of the liver and pancreas. Science. - 2008. - Vol. 322. - P. 1490-1494.

12. M. Tanaka, T. Itoh, N. Tanimizu, A. Miyajima. Liver stem/progenitor cells: their characteristics and regulatory mechanisms. J Biochem. - 2011.

- Vol. 149. - P. 231-239.

13. Y. Miyaoka, A. Miyajima. To divide or not to divide: revisiting liver regeneration. Cell Division. - 2013. - Vol. 8(1):8. - P.1-12. DOI:10.1186/17471028-8-8.

14. K. Mahmoodi, B. West, P. Grigolini. Self-organizing complex networks: individual versus global rules. Frontiers in Physiology. - 2017. - Vol. 8. Article 478. - P.1-11. DOI:10.3389/fphys.2017.00478.

15. N. W. Watkins and others. 25 years of self-organized criticality: concepts and controversies. Space Science Reviews. - 2016. - Vol. 198(1-4) - P. 3-44. 
16. J. M. Cushing. Integrodifferential Equations and Delay Models in Population Dynamics. Springer-Verlag Berlin Heidelberg. - 1977. - Vol. 20 - 196 p.

17. C. Hutchison, D. M. Glover. Cell Cycle Control. Frontiers in molecular biology. - 1995. - Vol. 10. - 304 p.

18. K. J. Barnum, M. J. O'Connell. Cell Cycle Regulation by Checkpoints. Methods Mol Biol. - 2014. - Vol. 1170. - P. 29-40.

19. F. Marongiu et al. Hyperplasia vs Hypertrophy in Tissue Regeneration after Extensive Liver Resection. World Journal of Gastroenterology. - 2017. Vol. 23(10). - P. 1764-1770.

20. S. Fulda, A. M. Gorman, O. Hori, A. Samali. Cellular Stress Responses: Cell Survival and Cell Death. International Journal of Cell Biology. - 2010.P. 1-23.

Карєва В. В., Львов С. В. Математична модель процесів регенерації печінки: однорідне наближення. У даній статті розглядаються принципи, правила й механізми регуляції біологічних процесів під час розвитку і підтримки/відновлення (регенерації) динамічного гомеостазу органів і тканин організму. Ця проблема є однією з найбільш важливих фундаментальних проблем біології і медицини. Знання про правила і механізмах регенерації печінки організму є основою для розробки нових ефективних лікарських препаратів і вибору раціональних стратегій терапії захворювань печінки.

Згідно з поточними уявленнями теоретичної біології, розвиток, поведінка і підтримка динамічного гомеостазу визначається саморегуляцією, яка забезпечується за рахунок виникаючої самоорганізації біологічних процесівпідвпливом того чи іншого збурення.

Автори запропонували гіпотезу, що регуляція процесів підтримки/відновлення динамічного гомеостазу печінки на основі виникаючоїсамоорганізації відбувається згідно з деякими принципами, критеріями оптимальності, що склалися в ході еволюції організму.

Було розроблено узагальнену математичну модель, що явно залежить від керуючих параметрів. Запропонована математична модель процесів регенерації печінки є узагальненням таких відомих моделей популяційної динаміки, як узагальнені рівняння Лотки-Вольтерра, рівняння Лотки-Вольтерра з запізнілими аргументами, інтегродиференціальні рівняння Вольтерра.

Під час розробки моделі були зроблені наступні припущення: однорідне наближення, незалежність біологічних процесів, помірний токсичний вплив.

Дана модель буде базою для розробки більш складної моделі, яка буде враховувати стратегії регенерації за рахунок стовбурових клітин печінки і клітин Іто.У перспективі передбачається обгрунтувати принципи і критерії оптимальності регуляції процесів регенерації печінки і верифікувати їх у численних експериментах.

Ключові слова: математична модель, регенерація печінки, однорідне наближення

Article history: Received: 15 October 2018; Final form: 20 October 2018; Accepted: 21 October 2018. 